their condition of equilibrium. The greater part of the recovery takes place in the first week, and a considerable part in the course of the first day."

Now I have little doubt that both the want of accordance in the readings of the instrument with decreasing and then with increasing pressure, and the "after-working" mentioned above, are mainly, if not entirely, due to the imperfect elasticity of the corrugated disk that forms the cover of the exhausted chamber. No metal is perfectly elastic except with very minute stresses, and, as a consequence, when a metal is made to go through a complete stress cycle, there is always more or less lagging of strain behind stress. Again, there is with all metals more or less of time-lag, so that any alteration of stress does not produce its full effect all at once. Provided the temperature be kept constant, and the metal be not in any way disturbed, the time-lag is of such a nature that for equal successive intervals of time the corresponding changes of strain form a descending geometrical progression. With some metals, such as tempered steel, and with moderate stresses, the effects of imperfect elasticity are not of any material consequence. With others, however, such as aluminium and zinc, and the alloys of the latter metal-namely, brass, German-silver, \&c. - we meet with very appreciable deviations from the laws of perfect elasticity, even when the stresses used do not produce any permanent deformation. I understand that the corrugated cover is frequently made of an alloy something like German-silver, only softer. If this be so, I can well believe, from my experience of this alloy, that grave errors might arise, and probably have arisen, in the determinations of heights by the aneroid. If such a thing be feasible, I would suggest that the cover should be made of tempered steel.

King's College, Strand, February 19. Herbert TOMLINSON.

\section{Sparrows and Crocuses.}

THE time of year has arrived when we shall once more be hearing of the ravages of sparrows on crocus blooms, and the theories advanced in order to account for this propensity for destruction on the part of the sparrow in suburban gardens and elsewhere. One pet theory is that the sparrow has a fondness for yeilow, and shows it by destroying crocuses of that colour. Most unfortunately for the holders of such an opinion, the sparrow does not confine its attentions to yellow crocuses only, but attacks also the purple, white, \&c., as any grower of crocuses can prove. Undoubtedly the yellow suffer most, probably because they are the first to appear, and meet the birds' most pressing requirements. Moreover, the sparrows sometimes attack the flowers while still in the sheath, and before it is certain what colour they will be.

The object of the sparrow in destroying the flowers is simply to obtain succulent food at a time of year when such in the form of larvæ, \&c., is scarce. I have repeatedly watched the operation from my study window at a distance of very few feet. The stalk of the flower is bitten off by the bird some little distance below the flower itself. The succulent stalk is then nibbled away until the flower falls to pieces. The reproductive parts, and especially the anthers are not attacked, as some writers have asserted; but in consequence of the structure of the flower, they, like the petals and sepals, often fall away owing to the close nibbling of the bird.

Primroses also suffer. Early primroses are usually the common yellow form, ergo, according to theory-makers, the same cause is at work. So it is, but not in the direction they would have us believe. Here, again, I have distinctly seen the birds eating the flower-stalk.

I had written you a letter to the same effect as this about the same time last year, but from some cause or other it was not forwarded. I take this opportunity of possibly anticipating other letters on the same subject, and of inducing theorists to carefully watch the modus operandi as I have done before rushing into print.

Lewisham, February 26.

R. Mclachlan.

\section{A Possible Misunderstanding.}

I HAVE seen a report that, in a recent number of the Att 2 della K'egia Academia delle Scienze di Torino, Prof. Galileo Ferraris is credited with a statement which might mean that one of the formula which appear in a paper read by me before the Physical Society of London, in May 1888, was derived from a paper by him. If that be Signor Ferraris's meaning, he is entirely mistaken. My formulæe were obtained quite independently of Signor Ferraris or of anyone else.

Royal Naval College, February 29.

Thomas H. Blakesley.

\section{HERMANN KOPP.}

HERMANN FRANZ MORITZ KOPP, a distinguished German chemist, and one of that band of literary and scientific workers which, five-and-twenty years ago, made Heidelberg celebrated as a centre of intellectual activity, passed away from the scene of his labours on February 20, in the seventy-fifth year of his age. He had been in failing health for some time past, and although his recuperative power at times seemed wonderful, his friends were not wholly unprepared for his decease.

Born October 30, 1817, at Hanau, where his father, Johann Heinrich Kopp, practised as a physician, Hermann Kopp received his school training at the Gymnasium of his native town, and thence passed to the Universities of Heidelberg and Marburg with the object of studying the natural sciences, and more particularly chemistry. The special bent of his mind towards chemistry would seem to have been given by his father. The elder Kopp occasionally busied himself with experimental chemistry, and Leonhard's Taschenbuch and Gehlen's Journal contain papers by him on mineral analyses and on investigations relating to physiological chemical products.

In 1839, Hermann Kopp joined Liebig at. Giessen, drawn thither by the extraordinary influence which has made the little laboratory on the banks of the Lahn for ever famous in the history of chemical science. For nearly a quarter of a century Kopp found in Giessen full scope for his scientific and literary activity. In 1841 he became a privat-docent in the University, two years later he was made an extraordinary professor, and in I 853 he became ordinary professor. In 1864 he was called to Heidelberg, where he remained until his death, occupying himself latterly with lectures on the history of chemistry, and on chemical crystallography.

At the very outset of his career as an investigator, Kopp seems to have devoted himself to that field of inquiry in which his chief distinction as an original worker was won, viz. physical chemistry. One of his earliest papers-" "Ueber die Vorausbestimmung des specifischen Gewichts einiger Klassen chemischer Verbindungen," published in Poggendorff's Annalen in the year he went to Giessen--deals with the conception of specific volume, which he here introduces for the first time. During the ensuing five-and-twenty years, so far as laboratory work was concerned, he was almost entirely occupied in attempting to trace experimentally the connection between the physical properties of substances and their chemical nature. We owe to Kopp, in fact, all our broad fundamental generalizations concerning the connection between the molecular weights, relative densities, boiling-points, and specific heats of substances, and on the relations of crystalline form and chemical constitution to specific volume. For work of this kind Kopp was eminently well fitted. To remarkable manipulative dexterity and great ingenuity-much of which, as in the case of Wollaston, was spent in satisfying a certain fastidiousness for simplicity of apparatus and experimental method-was joined the most scrupulous sense of accuracy and illimitable patience. As proof of his accuracy, it may be stated that, although many observers have had occasion, from time to time, to review his work on the thermal expansion of liquids-and on a far more ambitious scale, and with more refined apparatus, than was possible half a century ago-his determinations have been practically unchallenged, and retain their place among the best ascertained constants of their kind.

No. I I67, VOL. 45] 
Kopp's scientific papers dealing with his laboratory labours mainly appeared in Poggendorff's Annalen der Physik und Chemie, and latterly in Liebig's Annalen der Chemie. One or two of his contributions appeared in the Philosophical Magazine, and the Chemical Society published his elaborate memoir on the specific heats of compound substances, in which he sought to develop and extend Naumann's law. But, compared with those of his contemporaries, Liebig and Wöhler, his papers are comparatively few in number. This is largely accounted for by the very character of his investigations. His communications were, for the most part, records of measurement, often troublesome and tedious in their nature, and followed by long and wearisome calculations; and in many cases the substances with which he experimented could only be prepared in a state of purity by longcontinued operations. It is only those who have engaged in work of this kind that can properly appreciate the amount of labour thus involved. The nature of the relations which he strove to elucidate necessitated the determination of the particular physical constants of some scores of substances ; indeed, to Kopp, their number was only limited by the extent of his knowledge of the existence of their isomerides and homologues. Much of this work was necessarily of a pioneer character. It stands, in fact, to our later knowledge much in the same way as does the work of Boyle, Mariotte, and Gay-Lussac to the fuller development of the gaseous laws which we have witnessed during the past few years. Kopp, indeed, was among the earliest to venture into a province of which he actually was the first to recognize the exceeding fruitfulness. Its soil, however, is not of that nature which, tickled with a hoe, laughs with a harvest ; it is only with much tillage and patient toil-the conjoint work of physicists and chemists - that it can be made to yield its riches. It is, however, by such work that the supreme secret-the true nature of the form of force with which the chemist is mainly concerned, the real nature of chemical affinity -will be revealed.

Kopp is known to the literary world mainly by his great work on the "History of Chemistry" (Brunswick, I $843-47,4$ vols.). The amount of labour and research involved in the preparation of this work was simply stupendous. It is not many men of twenty-five who would have either the skill or the patience to attack the mass of literature which embalms the chemical lore of the ancient peoples of the East, or who would devote years to extracting what there is of science or philosophy from the jargon of the alchemists, or the mystical writings of the Rosicrucians. It is hardly to be wondered at that nearly every subsequent writer on the history of chemistry has been content to take his facts from Kopp: their works, so far as they relate to the early history of the science, are based, and, for the most part, avowedly so, on his researches. From time to time Kopp published supplementary volumes on the same subject. In 1 869-75 appeared his "Beiträge zur Geschichte der Chemie" (Brunswick, three parts); in $1871-73$ the "Entwicklung der Chemie in neuerer Zeit"; and, in I886, "Die Alchemie in älterer und neuerer Zeit" (Heidelberg, 2 vols.). In 1849 appeared his "Einleitung in die Krystallographie" (Brunswick; 2nd ed., 1862) and in conjunction with his Giessen colleagues, Buff and Zamminer, he published his "Lehrbuch der physikal. und theoretischen Cnemie" (Brunswick, 1857; 2nd ed., I 863), which constitutes a portion of the well-known Graham-Otto's "Lehrbuch der Chemie," one of the standard text-books in Germany and Austria.

In 1848 , Kopp joined Liebig in the production of the Jahresbericht iiber die Fortschritte der Chemie, which he continued to edit, latterly with Heinrich Will, down to 1862. In 185 he became the acting editor of the $A n$ nalen der Chemie, and although, with increasing years and failing health, he was obliged to relinquish the re- sponsible management, he continued to the last to take a lively interest in the fortunes of the periodical.

Kopp's services to chemical science were recognized by our own Chemical Society as far back as 1849 ; and, with the exceptions of Bunsen, who is the Doyen of the Forty, and who celebrates his jubilee as a Foreign Member this year, and of Fresenius, who was elected in 1844 , he was the oldest Foreign Member of the Society. He was made an honorary member of the German Chemical Society in I 869 , and in 1888 he was elected a Foreign Member of the Royal Society.

Kopp was a good linguist and an omnivorous reader, not only of matters scientific, but also of history and contemporary politics. He was remarkably catholic in his tastes and wide in his sympathies. Indeed, no man could be further removed than he in this respect from the conventional idea of the German professor. Hewas a constant reader of NATURE, and hence was well informed of the march of events, scientific and educational, in this country. The writer of this notice, who counts it a great privilege to be able to number himself among his pupils, when visiting him in Heidelberg last spring was astonished to find how fully and accurately he had grasped the details and bearings of the projected scheme for the new University in London, as it was at that time understood. He was much interested, too, in the great experiment which the County Councils have undertaken in relation to secondary education, but of the result of that experiment in its present form he expressed himself as not very hopeful. His extraordinary range of information, his wonderfully retentive memory, his geniality, his keen sense of humour, his fund of anecdote, and exceptional conversational powers, made him one of the most delightful of companions. Even in the pages of the Jahresbericht, the evidences of Kopp's humour are to be found. In abstracting the well-known paper by Playfair and Joule on the Specific Volume of Hydrated Salts, he is constrained to remark:-

"Die Verfasser dieser Abhandlung sind anerkannte Forscher, aber das hebt die Unbegreiflichkeit nicht auf, dass in dem phosphorsauren Natron, welches wir vor uns sehen, es nur das Wasser sein soll, welches den Raum erfullt, neither acid nor base occupy space. Wie durch Zauberei kommen die letztern erst bei dem Erhitzen räumlich zum Vorschein.-Säure und Basis nehmen hier keinen Raum ein, weil die Annahme, das Wasser sei hier mit dem spec. Volum des Eises vorhanden, gemacht worden ist, und nach ihr fur Säure und Basis Nichts übrig bleibt. Jene Katze wurde von ihrem Herrn vermisst, obgleich er sie unter Händen hielt, weil er die Annahme gemacht hatte, sie habe das Fleisch gefressen. An diese merkwürdige Begebenheit wird man sehr oft in den Naturwissenschaften erinnert. Ein Mann supponirte, seine Katze habe Fleisch gefressen; er wog sie, und da sie grade so viel wog als das abhanden gekommene Fleisch, sagte er verwundert: "hier ist mein Fleisch; wo bleibt meine Katze?'"

As Mr. Oscar Wilde has just reminded us, we are far too serious nowadays; our Jahresberichte, Berichte, and Chemical Society Journals have grown to be fat, unwieldy tomes, and the printers' bills grow steadily year by year; otherwise some of us would not be greatly shocked to find our scientific reading occasionally lightened a little in this way. For it was the saying of an ancient sage that humour is the only test of gravity; and gravity, of humour.

By no one will Kopp's departure be more keenly felt than by Bunsen, his friend and colleague for more than a quarter of a century. The strollers along the Anlage will miss the quaint little figure on its way to the daily visit to the old veteran, who, rich in honour and in years, is now the last of that famous triumvirate-Bunsen, Kirchhoff, and Kopp-the memory of whose services the world will not willingly let die.
T. E. THORPE.

NO. 1167 , VOL. 45] 